\title{
Risk and Opportunity Assessment Model for CSR Initiatives in the Face of Coronavirus
}

\author{
Maria Krechowicz *(D) and Katarzyna Kiliańska (D)
}

Faculty of Management and Computer Modelling, Kielce University of Technology, 25-314 Kielce, Poland; kkilianska@tu.kielce.pl

* Correspondence: mkrechowicz@tu.kielce.pl

Citation: Krechowicz, M.; Kiliańska, K. Risk and Opportunity Assessment Model for CSR Initiatives in the Face of Coronavirus. Sustainability 2021, 13, 6177. https://doi.org/10.3390/ su13116177

Academic Editors:

Isabel-María Garcia-Sanchez, Filippo Vitolla and Nicola Raimo

Received: 5 May 2021

Accepted: 27 May 2021

Published: 31 May 2021

Publisher's Note: MDPI stays neutral with regard to jurisdictional claims in published maps and institutional affiliations.

Copyright: (c) 2021 by the authors. Licensee MDPI, Basel, Switzerland. This article is an open access article distributed under the terms and conditions of the Creative Commons Attribution (CC BY) license (https:// creativecommons.org/licenses/by/ $4.0 /)$.

\begin{abstract}
This paper concerns an important and current problem of taking Corporate Social Responsibility (CSR) initiatives in the specific market conditions of the COVID-19 pandemic. CSR activities, aimed at combating COVID-19, contribute to creating favorable conditions for the sustainable development of enterprises and the entire society. In this work, analysis of the survey results, interviews with the initiatives' beneficiaries, and brainstorm sessions with CSR specialists and companies' employees allowed us to identify risk and opportunity categories, factors, and develop scales for their probability and consequences assessment. Survey results revealed that socially responsible actions are important in the fight against the coronavirus pandemic, and social expectations, in this regard, are growing. Two-parametric risk/opportunity matrix was used to calculate risk/opportunity level. The aim of this work is to present a new model of risk and opportunity assessment dedicated to organizations carrying out of CSR ventures in the pandemic era. The proposed risk and opportunity assessment model is an effective tool to identify the CSR initiative advantages and drawbacks, as well as a starting point for managing them, to maximize chances and minimize threats. Three examples of practical applications of the proposed model confirm that it can be successfully used in practice. The developed model is based on universal assumptions and criteria, so that it can be used in any country struggling with the pandemic.
\end{abstract}

Keywords: risk and opportunity assessment; Corporate Social Responsibility; COVID-19

\section{Introduction}

Currently, almost the entire world tries to face the virus called COVID-19 [1], which spread very quickly and disrupted the functioning of many enterprises. It also poses a threat to numerous economies $[2,3]$. Enterprises have to deal with new problems that they did not have to solve before [4]. Solving these problems requires the ability to respond to an external threat such as the COVID-19 pandemic [5], the ability to quickly adapt to changes, modify methods of doing business [6], and taking on new challenges that arose with the advent of a pandemic. The lack of specific arrangements, patterns, and procedures for dealing with a pandemic forced many entities to act intuitively in various aspects of their activities [7].

Governments in many countries have introduced a variety of countermeasures to minimize the spread of the virus. The negative effects of legal regulations have been felt not only by the public. The decisions of individual governments also translated into unfavorable conditions for running a business. Compliance with the introduced regulations meant that many enterprises were somehow forced to suspend their activities, or close them, due to difficulties in generating revenues and an inability to settle basic obligations towards cooperators and the state [8,9].

Corporate Social Responsibility (CSR) is a complex and interdisciplinary term [10], encompassing the active, voluntary dedication of enterprise resources to the implementation of activities aimed at improving quality of life in society [11], improving the quality of the environment, solving social problems [12], and contributing to sustainable economic development. CSR is connected with responding to the expectations of stakeholders [13] in 
the scope beyond its own economic interests [14] and applicable law [15]. It is difficult due to the contradiction of interests and expectations of various stakeholder groups, which a socially responsible enterprise must reconcile with [10].

CSR is a vital element of sustainable development [16-18]. The relationship between socially responsible business and sustainable development has been strictly defined in the ISO 26000 standard [19]. The standard describes the principles of CSR and key areas of enterprise activity in maximizing their contribution to sustainable development. It is especially important nowadays, when enterprises face difficult conditions, for sustainable development in the face of the crisis caused by the COVID-19 pandemic. The pandemic also has serious implications for social sustainability. CSR activities, aimed at combating COVID-19, contribute to creating favorable conditions for the sustainable development of enterprises and the entire society. The business sphere is responsible for sustainable development [20]. Therefore, it is interesting to consider sustainable development and CSR through the prism of the risks and opportunities that arise from taking up this type of activity.

CSR receives much attention among businesses because of the pressure from different stakeholders, including customers, competitors, and others, to be engaged in sustainable practices [21].In turn, in the face of the pandemic, enterprises have expanded their responsibility for society, and, in particular, for those social groups which, by fighting the pandemic, enable the restoration of conditions for sustainable development. It has been shown that undertaking CSR activities constitutes a source of opportunities and threats for enterprises. The pandemic redefined the relationship between enterprises, society, and government [12], which, in the face of the threat, began to cooperate more closely to avoid the negative consequences of the COVID-19 pandemic. The pandemic has motivated companies to actively participate in the fight against it [22]. Economic entities undertook to meet social needs, regarding health protection or education, in a wider scope than before, despite the fact that it is the responsibility of the government [23]. In other words, by undertaking socially responsible initiatives, enterprises contributed to meeting public needs and create public goods that the government cannot provide on its own [24]. As a result, the boundaries between individual sectors of the economy are blurred, and the involvement of many parties may contribute to the achievement of socially responsible goals [25].

The fact that enterprises undertake socially responsible activities may be economically utilitarian for them and serve to generate benefits [26], including image improvement [27] and reputation $[28,29]$. According to the literature, involvement in CSR contributes to building lasting, loyal relations with interest groups [30,31], stimulating the internal motivation of employees [32] and influencing the attractiveness of the company as a potential employer [33], shaping the attitude of stakeholders to the company and improving its competitive position [34]. However, this change is not permanent because it depends on the perception of the company's activities [35], which may have a negative impact on the image the company's reputation [36]. Nevertheless, the positive reaction of stakeholders, to the activities within the CSR, may be determined by whether they see the benefits of these activities for themselves [37].

CSR should be envisaged not only with benefits (for the company and interests) but also with risks. CSR is associated with the allocation of the company's resources for the implementation of prosocial tasks, which is associated with the risk of slowing down the dynamics of the company's development [38]. Moreover, socially responsible initiatives should be flexible and have the ability to adapt to the changing conditions in which they are performed. The lack of continuous monitoring means that the changes in the above-mentioned conditions do not alter the way of achieving social goals. It is connected with the risk of making mistakes, and incurring costs, that could have been avoided. Treating the CSR as something additional, and not a relatively permanent part of the activities of enterprises, creates the risk of a slowdown in the achievement of the company's strategic goals. Some CSR activities were criticized for not being good enough. Banerjee [39] found out that sometimes CSR could not be considered as "truly social," 
as they were only a tool to improve the financial performance of the company in a long term. It may have a negative impact on the company's image and reputation [34].

To benefit from CSR activities, companies should take measures to reduce the risk associated with taking them [40]. It is noted in the literature that CSR induces new risks [41], but the risk related to CSR activities of enterprises has not been well recognized in the literature so far. It is still a poorly explored area with many unknowns. The subject of using positive aspects, resulting from CSR initiatives, as a support of the risk management process of the organization was taken in [42]. The relationship between risk management and CSR was described in [43,44]. In [27], it was stressed that it is vital to identify variables and factors that influence the behavior of CSR initiatives interest groups, and study their impact on organizational risk management. However, the analysis of the risks and opportunities, and the possibility of risk-to-opportunity status change, have not been considered in the literature so far. Moreover, risk factors specific for CSR actions have not been presented and analyzed in the literature yet. All in all, this work would be the first attempt to carry out the opportunity and risk assessment of CSR initiatives aiming to fight against coronavirus.

The growing number of socially responsible initiatives undertaken, in the era of a pandemic, may contribute not only to the sustainable development of enterprises and society but also, to the need to take certain risks related to the implementation of such activities. Therefore, it is vital to conduct a risk/opportunity assessment, which allows both to protect against undesirable consequences, resulting from the implementation of the CSR initiative, and to maximize the opportunities related to this type of activity.

The classical definition of risk states that it is the product of the probability of an event, assessed negatively, and its consequences [45]. Still, there is a need to consider broader risk definitions, including positive and negative outcomes. This dualism of risk is very well reflected in the Chinese symbol of risk, which combines danger and opportunity. It illustrates the positive and negative sides of risk. It should be noted that risk should not be associated with threats only, and therefore, the focus should not only be on risk minimization and protection, as this approach also reduces the potential of opportunities. According to the new ISO 31000 [46], organizations should focus on increasing the likelihood of achieving objectives, improving the identification of opportunities and threats, together, with effective risk treatment. It is essential to adapt the risk management process to the specificity of the operation and context of the enterprise [47]. There are many methods that were successfully applied in risk assessment models, e.g., two-, three-, or five-parametric risk estimation matrix [48], fuzzy fault tree analysis [49], hybrid fuzzy fault and event tree analysis [50], event tree analysis [51], and Failure Mode and Effects Analysis [52,53]. Besides this, machine learning has recently become increasingly used in risk assessment [54-56].

The main hypothesis, which was formulated in the study, is the following: the proposed model enables risk and opportunity assessment of CSR activities aimed at combating the COVID-19 pandemic. The first objective of this work was to verify how the society assesses the involvement of enterprises in undertaking socially responsible activities in the time of a pandemic. Using the proprietary research tool-the questionnaire, a primary study was conducted, in which 207 respondents assessed 22 CSR actions taken by Polish enterprises, in terms of their importance in the fight against coronavirus and the impact on the company's image. Moreover, the respondents also answered three questions related to their general perception of the enterprises' activities in the fight against coronavirus in terms of whether they are, in their opinion, sufficient, selflessly undertaken, and whether respondents expect greater business involvement in CSR actions in the pandemic era. The second objective was to identify risk and opportunity factors associated with undertaking socially responsible initiatives by enterprises and develop a new model of their assessment. The practical application of the proposed model was shown on three examples.

The contribution of this work, to the body of knowledge, comes down to the provision of new knowledge in the area of verifying how the society assesses the involvement of enterprises in undertaking socially responsible activities in the time of a pandemic, 
identification of risk/opportunity categories, and factors associated with undertaking socially responsible initiatives by enterprises, as well as the development of a new model, dedicated to risk/opportunity assessment, of CSR initiatives taken by enterprises.

\section{The Proposed Approach}

The proposed approach of risk/opportunity assessment includes six steps: gathering data about CSR initiatives to fight coronavirus, conducting a survey and interviews with the beneficiaries of CSR initiatives, identification, and description, of risk/opportunity categories as well as risk/opportunity factors, development and description of risk/opportunity consequences and probability scales, risk/opportunity assessment with evaluation, using 2-paramertic matrix, and implementation of the proposed model on 3 examples. Figure 1 presents the diagram of the proposed approach. It is important to stress that the developed model (including risk/opportunity categories, factors, and scales for their assessment) is based on universal assumptions and criteria, so that it can be used in any country struggling with the COVID-19 pandemic.

Gathering data about CSR initiatives aiming to fight with the coronavirus -literature study

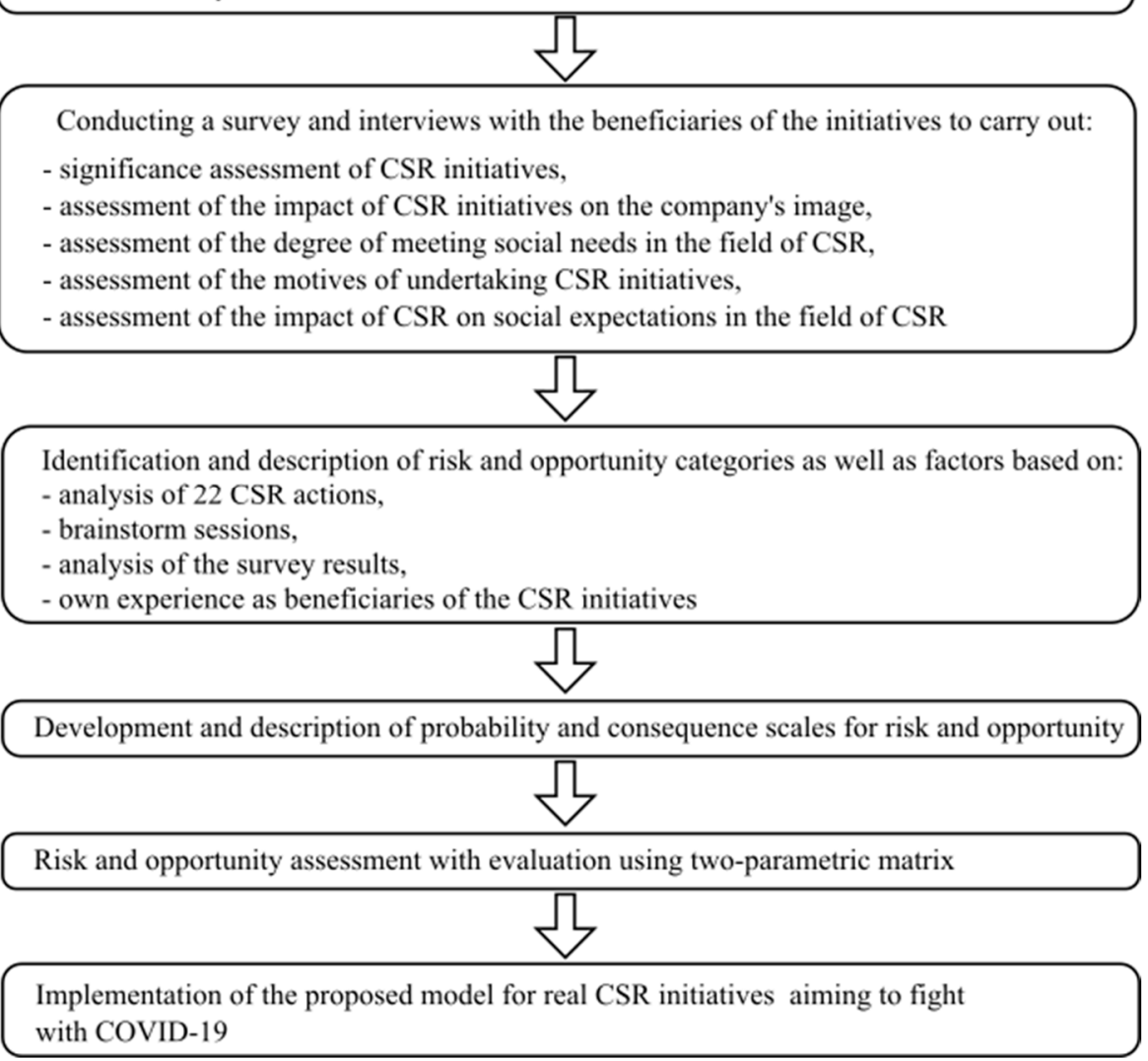

Figure 1. The proposed approach to risk and opportunity assessment.

\subsection{Defining the Subject of the Study}

The data about the 22 most widespread in the media Polish CSR initiatives to fight with COVID-19 was gathered and analyzed. Nine initiatives, with the highest significance scores, are presented in this paper. Short descriptions of the analyzed CSR initiatives (depicted as D1-D9) are given below. The authors' observations show that similar initiatives were organized in other countries.

D1. Providing hospitals with protective helmets printed on 3D printers (Kielce University of Technology) 
Kielce University of Technology was involved in solving the problem of the shortage of personal protective equipment, e.g., by printing protective helmets on 3D printers. University employees and students printed over 800 protective helmets, which were then donated to several hospitals.

D2. Sewing protective equipment for hospital workers (OTCF, tailor workshops)

Enterprises responded to the needs of hospital authorities who could not provide employees with personal protective equipment. They used their own resources to sew them. The owners of the 4F (OTCF) brand have given up sewing products for their customers to a different extent in favor of sewing protective masks and aprons. These entities sacrificed their resources (materials, machinery, and other equipment) and, thanks to the skills of their employees, were able to provide hospitals with the products they needed.

D3. Transfer of funds to fight coronavirus (Totalizator Sportowy-Lotto brand, GrupaLotos S.A., PGE)

The money donated by enterprises enabled the purchase of various types of personal protective equipment for medical services, disinfection devices for ambulances and hospital departments, and the adaptation of existing laboratories to conduct tests for COVID-19. This kind of support contributed to a more effective fight against the virus.

D4. Actions connected with voluntary making, and free delivery, of purchases to seniors

The elderly are the group that bears the greatest risk of loss of health due to COVID-19. They should avoid contact with others to minimize the risk of infection. This recommendation is difficult to follow, for example, in the face of the necessity to make everyday purchases. Some companies have tried to support the safety of seniors by bringing them home purchases.

D5. Free provision of Webex remote learning platform by Cisco

Due to the inability to conduct full-time classes, teachers and students had to use new technologies allowing for online learning. Cisco, as an entity that has tools for collaborating with teams, made them available to teachers free of charge. Thanks to it, the communication between teachers and students could be based, among others, on using videoconferences and the possibility of sharing the desktop of their computer by the teacher.

D6. Action "Double power to help"

At the end of March 2020, Santander Bank Poland together with the Santander Foundation began a charity campaign, as part of which funds were collected for the purchase of equipment and personal protective equipment for Polish hospitals. The bank doubled the amount of donations that, by the end of April 2020, were transferred to a special bank account opened for the needs of the campaign. Ultimately, PLN 3090605.86 was allocated for the purchase of the above-mentioned products under this initiative.

D7. Handing over to emergency services sports equipment that replaced personal protective equipment (OTCF)

The action was initiated by one of the hospitals struggling with the shortage of personal protective equipment. Due to the fact that safety glasses could not be bought anywhere, the president of OTCF, the owner of a popular sports brand, decided to donate some of his assortment to meet the needs reported by the hospital. He decided to donate 300 ski goggles to infectious diseases hospitals, which replaced the health care goggles.

D8. Action "We call meals/reinforcements"

The action is a grassroots, nationwide civic initiative, connected with supporting medical personnel during the fight against a pandemic in the field, of providing them with meals. Entities related to gastronomy and the production of food products donated their products or provided their services pro bono. All in all, thanks to this initiative, meals for over 22 thousand people were delivered to medical facilities.

D9. Launch of fluid production

In mid-March 2020, ORLEN OIL Production Plant, which manufactures windscreen washer fluids, coolants, lubricants, and oils, decided to carry out a laboratory analysis to change the direction of production to support the fight against COVID-19. All in all, the production lines were rearranged to produce a hand sanitizer. The new product was 
delivered to Material Reserve Agencies and was distributed at ORLEN petrol stations, thus ensuring access to the scarce product for society.

Due to the limited volume of the article, the characteristics of the remaining activities were not presented.

\subsection{Research Methodology}

The data used to develop this work was obtained with the help of: diagnostic surveys (survey technique, interview technique in the form of conversation) and brainstorming sessions with company employees and CSR specialists.

A survey and interviews with the beneficiaries of the CSR initiatives aiming to fight with coronavirus were carried out to:

- Verify how the society (in selected two groups: students and seniors) assesses the involvement of enterprises in undertaking socially responsible activities in the time of a pandemic;

- Assess the importance of the actions taken in the fight against coronavirus and their impact on the company's reputation;

- Define general respondents' perception of enterprises' activities in the fight against coronavirus, in terms of whether they are, in their opinion, sufficient, selflessly undertaken, and whether respondents expect greater business involvement in CSR actions in the pandemic era;

- Select the most important CSR activities, according to the respondents, for further analysis (risk and opportunities assessment).

- The subjective scope of the research was deliberately defined to include students and seniors. The two groups indicated were a valuable source of information on the evaluation of socially responsible initiatives undertaken in the pandemic era.

The spatial scope of the study covered Poland. The subjective scope of the study was deliberately defined to include students and seniors. The two indicated groups were a valuable source of information on the evaluation of socially responsible initiatives undertaken in the pandemic era. The legitimacy of such a selection of respondents is confirmed by the fact that these are two groups that were severely affected by the effects of the pandemic. The pandemic prevented students from participating in classes, conducted on-site, at the university. Students were forced to quickly adapt to remote learning (organize the necessary equipment to participate in classes, ensure sufficient internet connection). Lack of direct contact with lecturers, and difficulties in focusing attention on online classes, meant that students had to study the material themselves to a greater extent than before. Seniors were also a valuable source of information on the assessment of socially responsible initiatives undertaken in the pandemic era. They were a target group of beneficiaries of some CSR actions. Moreover, the consequences of infection for elderly people were usually more severe than in the case of younger people. Elderly people, more often than young people, struggle with chronic diseases, which increases the risk of a severe course of COVID-19 infection and increases the risk of death as a result of COVID-19 infection [57,58]. The spatial scope of the study covered Poland.

A deliberate sampling method was used in the study. Using the survey method, the original research was carried out with the use of the proprietary research tool-the questionnaire. The authors' intention was to use the survey to verify how people in the selected groups assessed the involvement of enterprises in undertaking socially responsible activities in the time of a pandemic. For the purposes of the study, the following research questions were formulated:

RQ1: Which CSR activities were significant in the fight against the COVID-19 pandemic in the opinion of students and seniors?

$\mathrm{RQ2}$ : What is the impact of undertaking socially responsible activities by enterprises on their image in the time of a pandemic?

RQ3: What are the opinions of students and seniors on the sufficiency of CSR activities undertaken in the time of a pandemic? 
RQ4: How the COVID-19 pandemic influenced the level of expectations of students and seniors regarding undertaking CSR activities?

RQ5: What are the motives for undertaking CSR activities aiming to combat COVID-19 pandemic according to students and seniors?

The following issues were measured in the survey:

- significance of CSR activities in the pandemic era-a 3-level ordinal scale (low, medium, and high significance) was applied,

- the strength of the positive/negative impact of CSR activities undertaken in the pandemic era on the image of entities implementing the above-mentioned activities-a 6-step semantic scale was used for the measurement (very strong negative, strong negative, weak negative, weak positive, strong positive, very strong positive impact),

- If, in the opinion of the respondents, CSR activities during the pandemic were sufficient/if the respondents currently expect greater involvement of enterprises in carrying out socially responsible activities/what, according to the respondents, the motives for undertaking CSR activities in the time of the COVID-19 pandemic are-a nominal scale was used, taking into account the possibility of giving a neutral answer (affirmative, negative, and I have no opinion).

Before starting the actual surveying, pilot surveys were carried out to verify the correctness of the applied surveying procedure and validate the test tool.

The study used the Computer-Assisted Web Interview (CAWI) data collection technique, which, thanks to the lack of contact between the interviewer and the participants in the study, ensured both parties' safety and did not carry the risk of contracting the virus. The request to complete the survey questionnaire with a link to it was shared on social media. It made it possible to reach students, but also seniors who have accounts on this type of platform. A request to pass a link to the questionnaire and help elderly people to complete it was also sent to students, graduates, and employees of Polish universities.

Two control questions were included in the survey to verify the answers given by the respondents to show their truthfulness: "I believe that CSR activities taken in Poland during the coronavirus pandemic were not sufficient," "I believe that Polish CSR activities are not undertaken by companies disinterestedly." They verified respondents answers to RQ3 and RQ5. These questions made it possible, to some extent, to exclude deceptive responders. These questions were consistent with the content of the other 2 questions, but different in form and expression. The contradiction in the answers obtained indicated the respondent's dishonesty, which also disqualified their other answers and they were not taken into account in further analysis. Moreover, before starting the actual surveys, a pilot survey was carried out to check the correctness of the applied survey procedure and validation of the test tool.

The time range of data collection was 8 December 2020-21 May 2021. In the questionnaire, the respondents were asked, among others, to indicate their gender, and social status (student, employed, unemployed, pensioner). On the basis of these data, the authors created two respondents' groups for further analysis (students and seniors). There were 483 students and seniors who accepted the invitation to participate in the study. Finally, 304 fully completed questionnaires were qualified for data analysis (the effectiveness of obtaining data for analysis was $62.93 \%$ ). Based on the size of the entire population of Poles in the two groups: students and seniors, and the number of completely and correctly completed questionnaires, the maximum error was determined at the level of $6 \%$. The confidence level $\alpha=0.95$, and the estimated size of the fraction 0.5 were adopted for the calculations.

Regarding the representativeness of the sample in relation to the entire population of Poles, it should be emphasized that according to the gender control trait, the sample is representative. However, it should be noted that despite the efforts of the authors, the sample is not representative in terms of social status, as the actual study covered an insufficient number of seniors for the sample structure to reflect the social status structure of Poles. It was due to the restrictions introduced by the government, which made it impossible 
for the authors to reach the respondents in person. At the same time, Polish seniors are most affected by digital exclusion. According to the study conducted during the COVID-19 pandemic [59], approximately $80 \%$ of all people who have never used the Internet are aged 55-74. In addition, approximately $78 \%$ of this age group has never used a computer. Despite such obstacles, the authors tried to reach as many seniors as possible, but it was not enough to ensure that the entire group was representative in terms of social status. The research sample is characterized by a higher percentage of students in terms of social status (students) than in the Polish population. This is caused by the fact that young people have access to the Internet and are able to use it efficiently. They are more willing to fill out online surveys, which contributes to a higher rate of response.

The percentage of students and seniors (taking into account their gender) in the total population and the research sample is presented in Table 1.

Table 1. Structure of general and research population.

\begin{tabular}{ccc}
\hline Percentage of the Population & Poland & \multirow{2}{*}{ Research Sample } \\
\hline Social Status and Gender & $57.63 \%$ & 58.62 \\
\hline Female students & $42.37 \%$ & 41.38 \\
\hline Male students & $100 \%$ & $100 \%$ \\
\hline Sum & $57.02 \%$ & 57.50 \\
\hline Female seniors & $42.98 \%$ & 42.50 \\
\hline Male seniors & $100 \%$ & $100 \%$ \\
\hline Sum & &
\end{tabular}

The largest percentage of the respondents were women (59\%) and people living in cities (49\%). Taking into account education, the research sample included 30\% of people with higher education, $68 \%$ of people with secondary education, and $3 \%$ with basic vocational education.

In addition to CAWI surveys, interviews in the form of conversation were conducted with 10 students and 8 seniors in order to obtain more information on the reasons why they considered the analyzed CSR activities as negatively and positively influencing the image of enterprises. It supported identification of respondents' motives when answering. The answers were also very useful when describing the results obtained from the questionnaire survey.

During the brainstorming session, among 14 employees of enterprises engaged in the implementation of socially responsible activities and 5 specialists dealing with CSR, the following problem was posed: What are the risk/opportunity factors associated with taking CSR activities aiming to combat COVID-19 that that may be associated with each of the following categories (Significance of the action in the fight against coronavirus, Operational, Financial, Reputational, Safety and legal liability, Strategic). The participants of the brainstorm session presented various solutions to the problem, and the leaders of the session (authors of the paper) documented all their statements. Brainstorming provided the authors with-sometimes not obvious-proposals of risk factors and opportunities that could be overlooked. The collected proposals were assessed, in terms of their usefulness, to develop a list of risk factors and opportunities included in the model presented in this paper. Subsequently, the brainstorming session participants' suggestions were used to identify specific risk factors and opportunities.

\subsection{Surveys' and Interviews' Results}

The first question in the survey concerned the assessment of the significance of 22 Polish socially responsible activities aimed at fighting against COVID-19. A 5-point Likert scale was used in it, thanks to which the respondents determined the significance of individual activities, where grade 1 meant low significance and 5-high significance. Calculating the arithmetic mean was the basis for selecting 9 actions that, in the opinion of the respondents, 
were of the greatest importance in the fight against COVID-19. These activities were the focus of the authors of the study in the further research process. The accuracy of the selection of these activities, as those of the highest importance, is confirmed by the low values of the standard deviation, calculated on the basis of the assessment of the significance of these activities, made by the respondents (Table 2).

Table 2. Arithmetic mean and standard deviation of the assessment of the significance of socially responsible activities.

\begin{tabular}{cccc}
\hline $\begin{array}{c}\text { Action } \\
\text { Symbol }\end{array}$ & $\begin{array}{c}\text { Arithmetic } \\
\text { Average }\end{array}$ & $\begin{array}{c}\text { Standard } \\
\text { Deviation }\end{array}$ & Action \\
\hline D1 & 4.20 & 0.90 & $\begin{array}{c}\text { Providing hospitals with protective helmets printed on 3D printers (Kielce University } \\
\text { of Technology) }\end{array}$ \\
\hline D2 & 4.16 & 1.00 & Transfer of funds to fight coronavirus (Totalizator Sportowy-Lotto brand, \\
GrupaLotos S.A., PGE)
\end{tabular}

Based on the assessments of respondents, the number of respondents who considered D1-D9 activities to be low/medium/high significance, in the fight against COVID-19, was determined. In each of the analyzed 9 activities, the highest percentage of indications with the highest significance rating was recorded (minimum $64 \%$, maximum $82 \%$ ), as shown in Figure 2. It is interesting that in activities D1-D8 not more than $11 \%$ of respondents consider them to be of little importance in the fight against the pandemic. Only in the case of D9, such an answer was given by $19 \%$ of respondents. On this basis, it can be concluded that each analyzed socially responsible activity implemented by the business sphere, regardless of the type, stakeholders-beneficiaries of this activity, scope, or duration, is perceived by respondents as contributing to the fight against the pandemic.

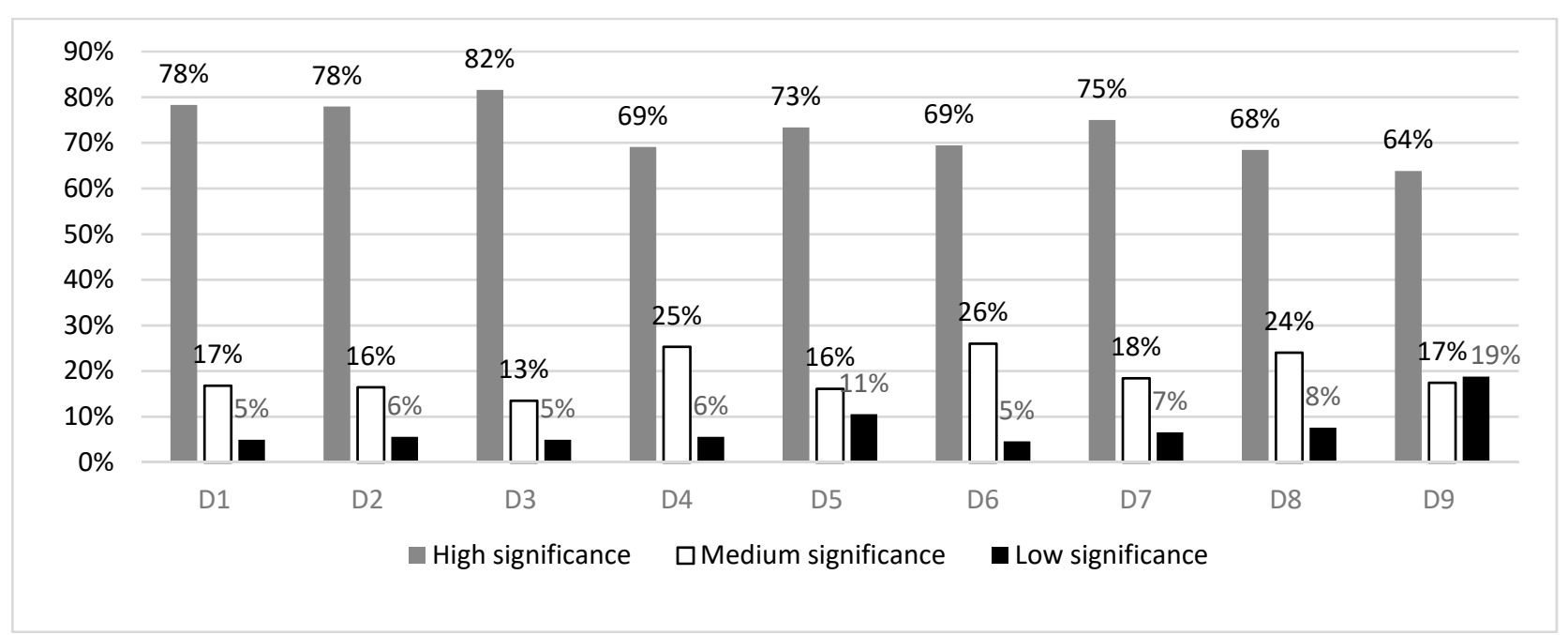

Figure 2. The importance of socially responsible actions in the fight against the COVID-19 pandemic. 
The respondents referred to how the fact of implementing socially responsible initiatives influenced the perception and image of the entity implementing the social enterprise. The analysis of the response frequency, in percentage, is presented in Table 3. The values in Table 3 do not add up to $100 \%$ because the analysis does not take into account the responses of those respondents who declared that they are not familiar with a given socially responsible initiative, which translates into no impact on the image of the implementing enterprise.

Table 3. Assessment of the strength of the impact of socially responsible activities on the image of the company.

\begin{tabular}{|c|c|c|c|c|c|c|c|c|c|}
\hline Students & D1 & D2 & D3 & D4 & D5 & D6 & D7 & D8 & D9 \\
\hline Very strong negative & & $2 \%$ & $2 \%$ & $1 \%$ & $1 \%$ & $0.4 \%$ & $1 \%$ & $1 \%$ & $5 \%$ \\
\hline Strong negative & & & & & $1 \%$ & $1 \%$ & & & $2 \%$ \\
\hline Weak negative & & $0.4 \%$ & $2 \%$ & & $0.4 \%$ & $6 \%$ & $0.4 \%$ & $4 \%$ & $5 \%$ \\
\hline Weak positive & $25 \%$ & $21 \%$ & $27 \%$ & $25 \%$ & $22 \%$ & $24 \%$ & $29 \%$ & $23 \%$ & $29 \%$ \\
\hline Strong positive & $19 \%$ & $20 \%$ & $20 \%$ & $25 \%$ & $23 \%$ & $16 \%$ & $19 \%$ & $17 \%$ & $21 \%$ \\
\hline Very strong positive & $44 \%$ & $45 \%$ & $25 \%$ & $31 \%$ & $40 \%$ & $34 \%$ & $35 \%$ & $31 \%$ & $25 \%$ \\
\hline Seniors & D1 & D2 & D3 & D4 & D5 & D6 & D7 & D8 & D9 \\
\hline Very strong negative & & & & & & & & & $11 \%$ \\
\hline Strong negative & & & & & & $1 \%$ & & & $6 \%$ \\
\hline Weak negative & & & $1 \%$ & $1 \%$ & & & & & $11 \%$ \\
\hline Weak positive & $17 \%$ & $22 \%$ & $17 \%$ & $13 \%$ & $19 \%$ & $13 \%$ & $15 \%$ & $13 \%$ & $13 \%$ \\
\hline Strong positive & $15 \%$ & $13 \%$ & $13 \%$ & $18 \%$ & $17 \%$ & $17 \%$ & $22 \%$ & $17 \%$ & $8 \%$ \\
\hline Very strong positive & $49 \%$ & $49 \%$ & $39 \%$ & $42 \%$ & $51 \%$ & $40 \%$ & $43 \%$ & $44 \%$ & $33 \%$ \\
\hline
\end{tabular}

The study revealed that socially responsible activities are generally perceived as positive and contribute to the company image of the entity implementing the social enterprise. A very strong positive impact of CSR activities on the image of the company for D1-D9 is declared by an average of $35 \%$ of students and $43 \%$ of seniors. A strong positive impact of CSR activities, on the image of the company for D1-D9, is declared by an average of $20 \%$ of students and $15 \%$ of seniors. A weak positive impact of CSR activities on the image of the company, for D1-D9, is declared by an average of $25 \%$ of students and $16 \%$ of seniors.

Based on the results of the study, it can be concluded that, in the case of students, only one activity (D1) did not reveal any negative impact on the image of the company implementing it. In the case of seniors, no negative impact on the company's image was noticed in as many as 5 CSR actions (D1, D2, D5, D7, D8). In the case of 8 CSR activities (D2-D9), the negative impact (regardless of its strength) of undertaking social initiatives by the company on its image was declared by an average $2 \%$ of students. In the case of 4 CSR activities that caused a negative perception of the image of the company by seniors (D3, D4, D6, and D9), the average was 5\%.

In the case of D6, such a distribution of answers may be determined by the fact that students had the largest share in the analyzed sample. During the interviews, users of the remote learning platform suggested that it did not always function properly-possibly due to insufficient bandwidth. It can be assumed that the image of the company providing the platform has suffered because the negative perception of a product that is made available for free to teachers and students affects the perception of the company as a whole.

During the interviews, in the form of conversation and brainstorming sessions with CSR specialists and enterprises employees, the authors obtained information allowing them to assume why D8, in the case of $5 \%$ of students, had a negative impact on the image of the entity donating sports equipment to medical service employees. The reason may be that sports equipment is not intended for the personal protection of medical services. It does not have appropriate certificates, does not meet the quality standards, and, therefore, 
does not ensure an adequate level of security against infection with the COVID-19 virus. It was also indicated that the equipment donated under D8 was a kind of way to get rid of the equipment from the warehouses, which did not enjoy the interest of customers, and the company had a problem with selling it.

D9 was the CSR activity, which, according to the largest number of respondents, has a negative impact on the image of PKN Orlen. On average, $4 \%$ of students and $9 \%$ of seniors indicated its negative impact on the image of the company. The analysis of the respondents' answers, and the conclusions of the interviews conducted with them allow to indicate the reasons why D9 could have a negative impact on the image of PKN Orlen. Despite a wide campaign informing about the availability of disinfectant liquid at gas stations, it was not possible to buy it. At gas stations, customers only received information from employees that they were still waiting for delivery. When the liquid physically appeared in stores, it cost PLN 95/5 dm3, which was criticized by the public-especially Internet users. Ultimately, PKN Orlen decided to lower the price of this liquid to PLN $49 / \mathrm{dm}^{3}$ [60]. It can be assumed that the feeling of unfair prices, and the physical lack of the desired product on store shelves, had a negative impact on the image of PKN Orlen.

One of the survey questions concerned the assessment of whether the actions undertaken by socially responsible enterprises in the pandemic era are, in the opinion of the respondents, sufficient (Figure 3). Based on the results of the analysis, it can be concluded that seniors, more often than students, declared that enterprises were sufficiently involved in the fight against thepandemic.

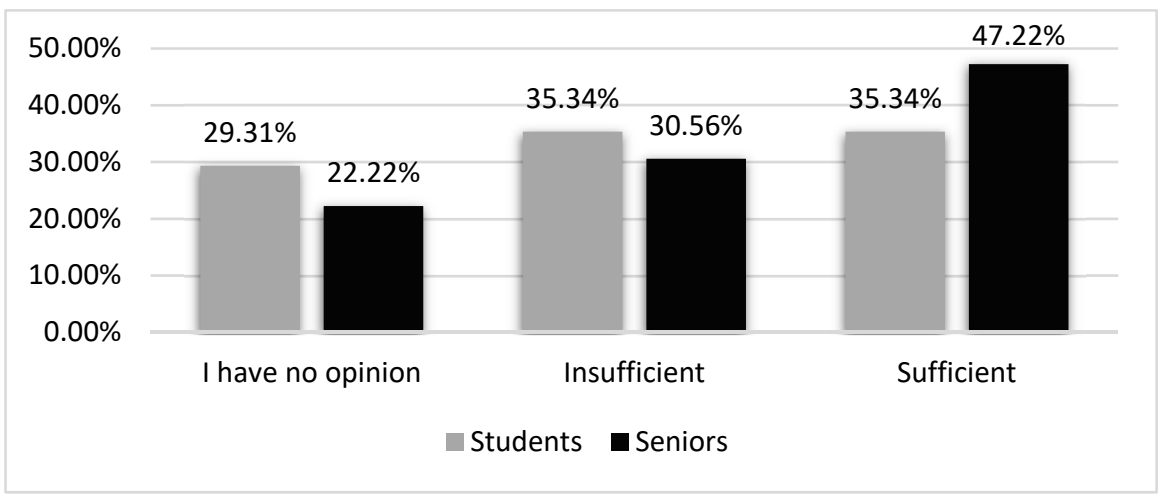

Figure 3. Assessment of the involvement of enterprises in fighting the pandemic.

The respondents' education level could determine the changes in the responses to the question of whether the CSR measures were sufficient in the pandemic era. The authors of the study checked whether the CSR activities aiming to fight the pandemic were considered as sufficient by respondents of different levels of education. Figure 4 presents the analysis of how respondents with different levels of education assessed if the CSR measures were sufficient in the pandemic era. The survey results show that the level of education of the respondents does not significantly differentiate their answers to this question (apart from the group of respondents with secondary education). Regardless of the level of education, the respondents most often admitted that CSR activities, at the time of the pandemic, were sufficient. However, the difference between Sufficient and Insufficient Response Rates was not large and averaged $3.95 \%$. In the case of respondents with secondary education, it is clear that all those who expressed their opinion on this subject admitted that CSR activities were sufficient. The distribution of answers of respondents with other education levels does not differ from the distribution of answers of all respondents. 


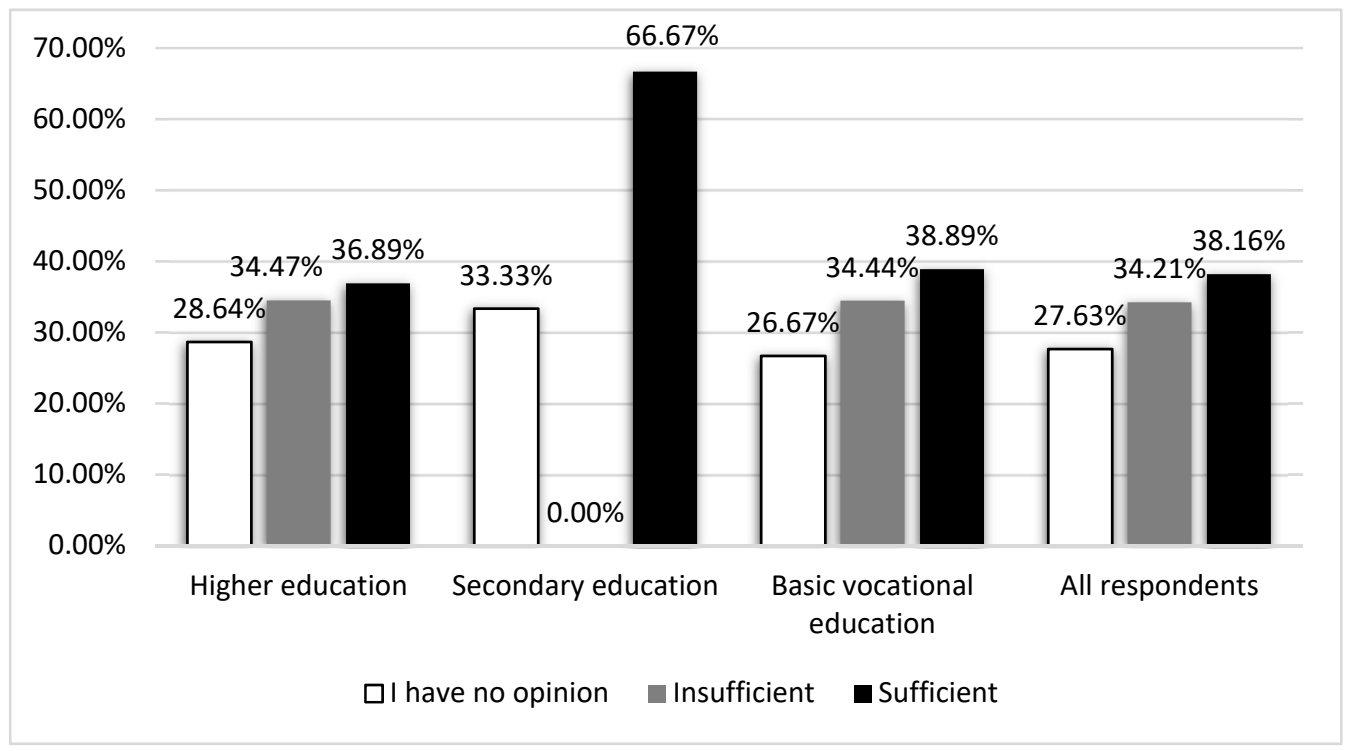

Figure 4. Assessment of the involvement of enterprises in fighting the pandemic and education of respondents.

The next question of the survey concerned the motivation of enterprises taking up socially responsible initiatives in the fight against COVID-19. This issue was assessed differently by all respondents. The analysis of the distribution of answers shows that all respondents, in general, believe that the motive was primarily the own benefits of enterprises $(44.41 \%)$. The answer of benefits for society was obtained by $37.83 \%$ of responses. However, in the case of students and seniors, there is a noticeable difference in the distribution of answers to this question. Seniors admit that enterprises selflessly undertook CSR activities to help fight the COVID-19 pandemic (58.33\%) much more often than students $(31.47 \%)$.The answer suggests that the above-mentioned CSR activities were undertaken with the intention of generating own benefits by enterprises was indicated by $19.44 \%$ of seniors and $52.16 \%$ of students. Based on the distribution of responses, it can be concluded that students, to a lesser extent than seniors, believe in the selflessness of socially responsible enterprises than seniors.

Figure 5 shows the distribution of answers to the analyzed question, taking into account the place of residence of the respondents. It shows that students living in the city, considerably more often than those living in the countryside, indicated that the motive for undertaking CSR activities in the time of the pandemic was for the own benefits of enterprise. A similar distribution appears in the responses of seniors living both in the city and in the village. Therefore, it can be assumed that city inhabitants, more often than rural inhabitants, see other reasons for undertaking socially responsible activities, in enterprises, than for the willingness to help the society in the fight against the pandemic. Such a conclusion is confirmed by the distribution of benefits for society answers.

When analyzing the responses by respondents' gender, both in the case of students and seniors, it can be noticed that men slightly more often declared that enterprises engage in CSR activities selflessly. The difference between the share of such responses between women and men was $1.97 \%$ for students and $5.19 \%$ for seniors. The distribution of answers to this question also indicates that, regardless of the subjective assessment of their financial situation, the respondents most often believed in the disinterestedness of enterprises undertaking socially responsible activities.

Respondents asked if they expected the business sector to be involved in CSR more often than before the pandemic, they most often admitted that they did: $47.41 \%$ of students and $75 \%$ of seniors. Less than $18.10 \%$ of students and $13.89 \%$ of seniors were of the opposite opinion. The analysis of the responses to the question, regarding the expectations of undertaking CSR activity in the future, showed that women more often than men declare that they expect the companies to be more involved in CSR activities. In the case of 
students, such an answer was given by over $5 \%$ more women than men, and in the case of seniors, by $7 \%$ more women than men. Figure 6 presents the distribution of answers to this question, taking into account the place of residence of students and seniors participating in the study. It shows that students, more often than seniors, found it difficult to answer this question- $47.03 \%$ of students chose the answer "I have no opinion" (Figure 6). It may be caused by the fact that it is more difficult for students to specifically formulate their opinions than for seniors who have more life experience and are able to clearly define their opinion on this subject.

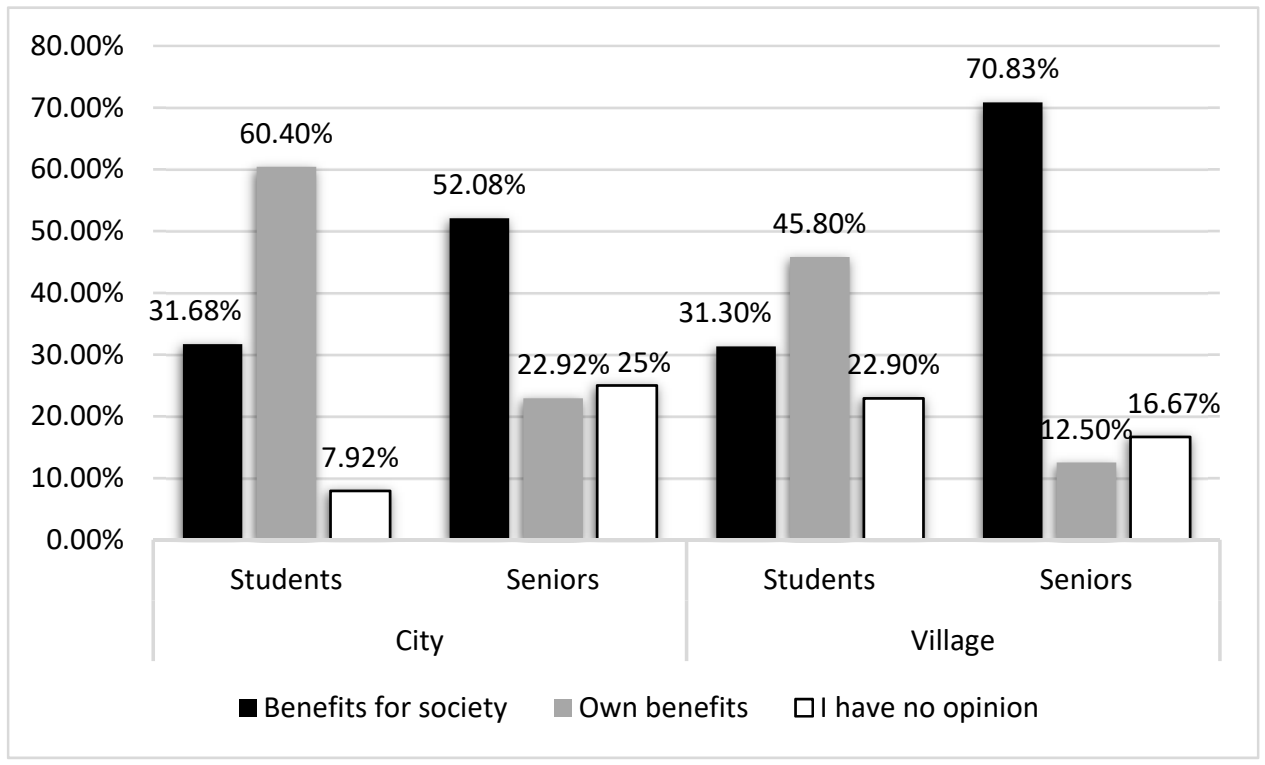

Figure 5. Motives for undertaking socially responsible activities by enterprise and respondent's place of residence.

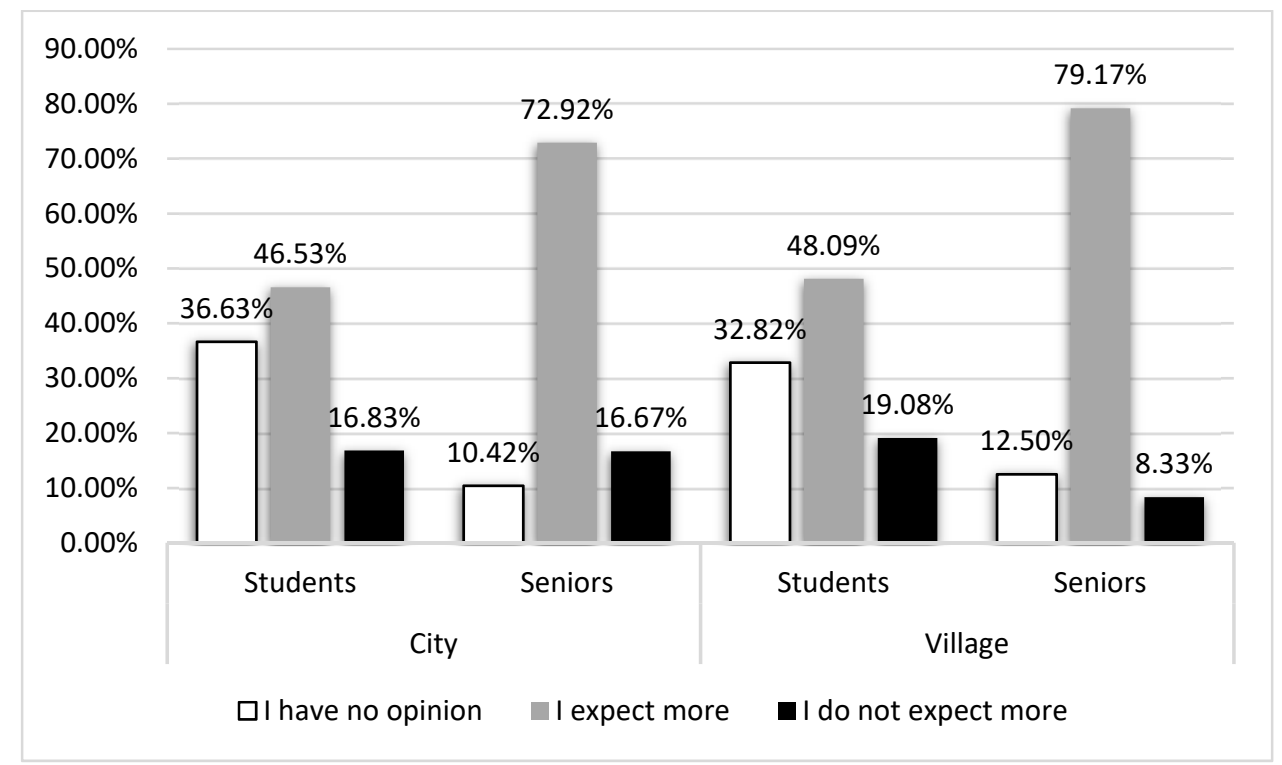

Figure 6. Respondents' expectations of taking CSR initiatives during a pandemic compared to expectations before the pandemic and the respondent's place of residence.

\subsection{Identification of Risk/Opportunity Categories and Factors}

In order to identify the risk/opportunity categories, as well as factors determining risk/opportunity level, it was needed to analyze CSR actions aiming to fight COVID-19, carry out brainstorm sessions with CSR specialists and enterprise employees, and conduct 
literature research. Besides this, the analysis of the survey results, and own experience as beneficiaries of those actions, were helpful.

Table 4 describes the different categories of risks and opportunities that are characteristic for socially responsible initiatives. It also indicates specific factors that should be taken into account when assessing the opportunities and risks resulting from the implementation of socially responsible initiatives.

Table 4. Risk/opportunity categories and factors determining risk or opportunity level.

\begin{tabular}{|c|c|c|}
\hline Category & Description & Risk/Opportunity Factors \\
\hline $\begin{array}{l}\text { Significance of the } \\
\text { action in the fight } \\
\text { against coronavirus }\end{array}$ & $\begin{array}{l}\text { Risk or opportunities } \\
\text { connected with the } \\
\text { significance of the } \\
\text { action in the fight } \\
\text { against coronavirus }\end{array}$ & $\begin{array}{l}\text { - } \quad \begin{array}{l}\text { geographic coverage (local, regional, national, international) } \\
\text { - }\end{array} \text { significance assessed on the basis of questionnaire surveys *, } \\
\text { type of beneficiaries (e.g., medical service, the whole society, social } \\
\text { group) } \\
\text { - } \quad \text { number of beneficiaries } \\
\text { - } \quad \text { the pace of implementing the socially responsible action plan } \\
\text { - } \quad \text { type of the action (e.g., financial support, production, enterprise } \\
\text { resources sharing) }\end{array}$ \\
\hline Operational & $\begin{array}{l}\text { Risks connected with } \\
\text { the impact of the } \\
\text { action taken on } \\
\text { management of usual } \\
\text { company activities } \\
\text { and the effectiveness, } \\
\text { efficiency, and caution } \\
\text { in using the organiza- } \\
\text { tion's resources }\end{array}$ & $\begin{array}{l}\text { - } \quad \text { the degree of involvement of human resources, machinery, materials, } \\
\text { money in the action taken } \\
\text { - } \quad \text { the degree of disruptions in vital every-day operation } \\
\text { - } \quad \text { the origin of resources (e.g., own, from the outside) } \\
\text { the effort required to prepare the action plan }\end{array}$ \\
\hline Financial & $\begin{array}{l}\text { Risks or opportunities } \\
\text { connected with the } \\
\text { impact of the action } \\
\text { taken on physical } \\
\text { assets as well as } \\
\text { financial resources }\end{array}$ & $\begin{array}{l}\text { - the impact of the action on the current and foreseen financial situation of } \\
\text { - the enterprise, } \\
\text { the possibility of introducing a product of CSR initiative as a new } \\
\text { commercially } \\
\text { - } \quad \text { the impact of the action taken on the current and forecasted sales } \\
\text { - the impact on the number of real customers } \\
\text { - } \quad \text { the impact of the action taken on the organization's budget, accounting } \\
\text { and reporting, investment capacity, credit rating, etc. }\end{array}$ \\
\hline Reputational & $\begin{array}{l}\text { Risk or opportunities } \\
\text { connected with the } \\
\text { impact of the action } \\
\text { taken on the reputation } \\
\text { of the company }\end{array}$ & $\begin{array}{l}\text { - impact of the action taken on the company's image and brand reputation } \\
\text { - } \quad \text { gased on the survey results), } \\
\text { - } \quad \text { targeting to a particular group of beneficiaries (a narrow/broad group of } \\
\text { beneficiaries, teenagers, students, elderly people, etc.) } \\
\text { - } \quad \text { the pace of introducing the action-the time from the idea of the action to } \\
\text { the time of introducing the real action, } \\
\text { - } \quad \text { the time of actively using the advantages of the initiative by beneficiaries } \\
\text { - } \quad \text { in the case of partnering CSR initiatives: exposure to the mishaps of the } \\
\text { - } \quad \text { partner } \\
\text { - } \quad \text { the impact on customers' loyalty }\end{array}$ \\
\hline $\begin{array}{c}\text { Safety and legal } \\
\text { liability }\end{array}$ & $\begin{array}{l}\text { Risks connected with } \\
\text { legal liability, injury or } \\
\text { damage, impacts of } \\
\text { accidental or } \\
\text { unintentional errors } \\
\text { or omissions }\end{array}$ & $\begin{array}{l}\text { - previous experience in providing services / production of a given type, } \\
\text { taking into account their specificity, as well as safety and legal } \\
\text { requirements related to them }\end{array}$ \\
\hline
\end{tabular}


Table 4. Cont.

\begin{tabular}{|c|c|c|}
\hline Category & Description & Risk/Opportunity Factors \\
\hline Strategic & $\begin{array}{l}\text { Impact of the action } \\
\text { taken on the } \\
\text { company's ability to } \\
\text { meet its strategic goals } \\
\text { and objectives }\end{array}$ & $\begin{array}{l}\text { - } \quad \text { the possibility of increasing the variety of services } \\
\text { - } \quad \text { the impact on competitive position } \\
\text { - } \quad \text { the impact on quality of the services provided } \\
\text { - } \quad \text { the opportunities/threats related to mission } \\
\text { - } \quad \text { the impact on the pace of achieving strategic goals }\end{array}$ \\
\hline
\end{tabular}

${ }^{*}$ It is advised to carry out the surveys before introducing CSR initiative.

\subsection{Development and Description of Risk/Opportunity Impact and Probability Scales}

To assess the risk or opportunity level connected with implementing CSR initiatives aiming to fight against COVID-19, it was needed to develop consequence and probability scales, which take into account the specificity of socially responsible initiatives during the pandemic. Tables 5 and 6 present the proposed risk/opportunity consequences scale. Table 7 presents the description of the probability scale, of the occurrence of risks and opportunities together, with the determination of the percentages.

Table 5. The proposed risk consequences scale.

\begin{tabular}{|c|c|c|}
\hline Impact Score & Short Name & Description \\
\hline 1 & $\begin{array}{l}\text { Minor } \\
(\mathrm{Mi})\end{array}$ & $\begin{array}{c}\text { Involves commitment of up to } 10 \% \text { of employees, minor involvement of machinery and } \\
\text { materials; minor disruptions in vital every-day operations and services; minor impact of } \\
\text { the action on the current and foreseen financial situation of the enterprise; minor negative } \\
\text { impact of the action taken on the current and forecast sales, organization's budget, } \\
\text { accounting and reporting, investment capacity, credit rating, etc.; slowing down on one } \\
\text { strategic goal of the company; no effect on company reputation or minor } \\
\text { negative publicity }\end{array}$ \\
\hline 2 & $\begin{array}{l}\text { Moderate } \\
\quad(\mathrm{Mo})\end{array}$ & $\begin{array}{l}\text { Involves commitment of } 11-20 \% \text { of employees; moderate involvement of machinery and } \\
\text { materials; moderate disruptions in vital every-day operations and services; moderate } \\
\text { negative impact of the action on the current and foreseen financial situation of the } \\
\text { enterprise; moderate impact of the action taken on the current and forecast sales, } \\
\text { organization's budget, accounting and reporting, investment capacity, credit rating, etc.; } \\
\text { slowing down on two strategic goals of the company; local negative publicity }\end{array}$ \\
\hline 3 & $\begin{array}{l}\text { Substantial } \\
(\mathrm{Su})\end{array}$ & $\begin{array}{c}\text { Involves commitment of } 21-30 \% \text { of employees; substantial involvement of machinery and } \\
\text { materials; substantial disruptions in vital every-day operations and services; substantial } \\
\text { negative impact of the action on the current and foreseen financial situation of the } \\
\text { enterprise; substantial impact of the action taken on the current and forecast sales, } \\
\text { organization's budget, accounting and reporting, investment capacity, credit rating, etc.; } \\
\text { slowing down more than two of the company's strategic goals; local negative publicity, } \\
\text { substantial reputation drop }\end{array}$ \\
\hline 4 & $\begin{array}{l}\text { Serious } \\
\text { (Si) }\end{array}$ & $\begin{array}{l}\text { Involves commitment of } 31-50 \% \text { of employees; significant involvement of machinery and } \\
\text { materials; serious disruptions in vital every-day operations and services; serious negative } \\
\text { impact of the action on the current and foreseen financial situation of the enterprise; } \\
\text { serious impact of the action taken on the current and forecast sales; organization's budget; } \\
\text { accounting and reporting, investment capacity; credit rating, etc.; stopping progress of } \\
\text { one strategic goal of the company; national negative publicity; serious reputation drop }\end{array}$ \\
\hline 5 & $\begin{array}{l}\text { Severe } \\
\text { (VS) }\end{array}$ & $\begin{array}{l}\text { Involves commitment of more than } 50 \% \text { of employees; very significant involvement of } \\
\text { machinery and materials; severe disruptions in vital every-day operations and services; } \\
\text { severe negative impact of the action on the current and foreseen financial situation of the } \\
\text { enterprise; severe impact of the action taken on the current and forecast sales, } \\
\text { organization's budget, accounting and reporting, investment capacity, credit rating, etc.; } \\
\text { stopping progress of more than one strategic goal of the company; national or } \\
\text { international negative publicity; severe reputation drop }\end{array}$ \\
\hline
\end{tabular}


Table 6. The proposed opportunity consequences scale.

\begin{tabular}{|c|c|c|}
\hline Impact Score & Short Name & Description \\
\hline 1 & $\begin{array}{l}\text { Minor } \\
(\mathrm{Mi})\end{array}$ & $\begin{array}{l}\text { Recognition of the initiative/company in a very narrow geographical scope, in a small } \\
\text { group of stakeholders; very weak positive impact on financial results; sales volume and } \\
\text { the number of loyal customers; very weak positive impact on the image and reputation of } \\
\text { the company; very low probability of introducing a socially responsible product/service } \\
\text { to commercial the company's sales offer; little experience in the implementation of } \\
\text { socially responsible initiatives (legal and organizational issues); no or negligible positive } \\
\text { impact on improving the company's competitive position and achieving strategic goals }\end{array}$ \\
\hline 2 & $\begin{array}{l}\text { Moderate } \\
\quad(\mathrm{Mo})\end{array}$ & $\begin{array}{l}\text { Recognition of the initiative/company in a narrow geographical scope, in a medium } \\
\text { group of stakeholders; weak positive impact on financial results, sales volume and the } \\
\text { number of loyal customers; weak positive impact on the image and reputation of the } \\
\text { company; low probability of introducing a socially responsible product/service to the } \\
\text { commercial sales offer of the company; very weak positive impact on improving the } \\
\text { company's competitive position and achieving strategic goals }\end{array}$ \\
\hline 3 & $\begin{array}{l}\text { Substantial } \\
(\mathrm{Su})\end{array}$ & $\begin{array}{l}\text { Recognition of the initiative/company in the medium geographic scope, among the } \\
\text { stakeholders; moderate positive impact on financial results, sales volume and the number } \\
\text { of loyal customers; moderate positive impact on the image and reputation of the company } \\
\text { average probability of introducing a socially responsible product/service to the } \\
\text { commercial sales offer of the company; weak improving the company's competitive } \\
\text { position and achieving strategic goals }\end{array}$ \\
\hline 4 & $\begin{array}{l}\text { Significant } \\
\quad(\mathrm{Si})\end{array}$ & $\begin{array}{l}\text { Recognition of the initiative/company in a wide geographical scope and among } \\
\text { stakeholders; strong positive impact on financial results, sales volume and the number of } \\
\text { loyal customers; strong positive impact on the image and reputation of the company; high } \\
\text { probability of introducing a socially responsible product/service to the commercial sales } \\
\text { offer of the company; strong a positive impact on improving the company's competitive } \\
\text { position and achieving strategic goals }\end{array}$ \\
\hline 5 & $\begin{array}{l}\text { Very significant } \\
\text { (VS) }\end{array}$ & $\begin{array}{l}\text { Recognition of the initiative/company in a very wide geographical scope and among } \\
\text { stakeholders; a very strong positive impact on financial results, sales volume and the } \\
\text { number of loyal customers; a very strong positive impact on the company's image and } \\
\text { reputation; negligible organizational, technical, financial requirements, etc.; very high the } \\
\text { probability of introducing a socially responsible product/service to the company's } \\
\text { commercial sales offer; extensive experience in the implementation of socially responsible } \\
\text { initiatives (legal and organizational issues); a very strong positive impact on improving } \\
\text { the company's competitive position and achieving strategic goals }\end{array}$ \\
\hline
\end{tabular}

Table 7. The proposed risk/opportunity probability scale.

\begin{tabular}{cccc}
\hline Score & Name & Description of Risk Scale & Description of Opportunity Scale \\
\hline 1 & $\begin{array}{c}\text { Low } \\
(\mathrm{L})\end{array}$ & $\begin{array}{c}\text { Unlikely or rare to happen, } \\
\text { probability of occurrence } \\
0-10 \%\end{array}$ & $\begin{array}{c}\text { Possible opportunity but it has not been fully confirmed } \\
\text { by previous analysis, probability of occurrence 0-25\% }\end{array}$ \\
\hline 2 & $\begin{array}{c}\text { Medium } \\
(\mathrm{M})\end{array}$ & $\begin{array}{c}\text { Likely to happen, probability } \\
\text { of occurrence 11-30\% }\end{array}$ & $\begin{array}{c}\text { Opportunity is likely to happen, may be achievable in } \\
\text { the case of introducing careful management, probability } \\
\text { of occurrence 26-70\% }\end{array}$ \\
\hline High & $\begin{array}{c}\text { Very likely to occur, } \\
\text { probability of occurrence } \\
\text { more than 31\% }\end{array}$ & $\begin{array}{c}\text { Indisputable opportunity that is very likely to occur } \\
\text { using the current management process, probability of } \\
\text { occurrence more than 70\% }\end{array}$ \\
\hline
\end{tabular}

\subsection{Risk/Opportunity Assessment with Evaluation Using Two-Parametric Matrix}

Two-parametric risk estimation matrix (Table 8) enables us to estimate risk as the product of the probability point scale and the consequences point scale related to the occurrence of a given event. If the level of risk for a given criterion is within the range of 1-3 points, it means that the risk is acceptable and its monitoring is recommended, if it is within the range of 4-9 points, it means that it is controlled and its reduction is 
recommended, and 10-15 points means that it is unacceptable and its absolute reduction is required. Opportunity is the product of the probability and the consequences related to the occurrence of a given event. If the opportunity level for a given criterion is between 1-3 points, it means that the analyzed CSR initiative is a small opportunity, if it is between 4-9 points, it means that it is an average opportunity, and 10-15 points means that it is a great opportunity for the development of the enterprise.

Table 8. Risk and opportunity assessment matrix.

\begin{tabular}{cccccc}
\hline Probability/Impact & $\mathbf{M i}=\mathbf{1}$ & $\mathbf{M o}=\mathbf{2}$ & $\mathbf{S u}=\mathbf{3}$ & $\mathbf{S i}=\mathbf{4}$ & VS = 5 \\
\hline $\mathbf{L}=\mathbf{1}$ & $\mathrm{LMi}=1$ & $\mathrm{LMo}=2$ & $\mathrm{LSu}=3$ & $\mathrm{LSi}=4$ & $\mathrm{LVS}=5$ \\
\hline $\mathbf{M}=\mathbf{2}$ & $\mathrm{MMi}=2$ & $\mathrm{MMo}=4$ & $\mathrm{MSu}=6$ & $\mathrm{MSi}=8$ & $\mathrm{MVS}=10$ \\
\hline $\mathbf{H}=\mathbf{3}$ & $\mathrm{HMi}=3$ & $\mathrm{HMo}=6$ & $\mathrm{HSu}=9$ & $\mathrm{HSi}=12$ & $\mathrm{HVS}=15$ \\
\hline
\end{tabular}

\section{Examples of Application of the Proposed Model}

The practical application of the proposed risk/opportunity assessment model was carried out on three examples (initiatives D4, D5, and D6). The analyzed initiatives differed in terms of many factors, e.g., the geographical coverage of the action, target group, the type of support, the degree of involvement of human resources, machinery, materials in the action taken, and the degree of public involvement. Such diversity allows for the achievement of a good, pre-coded picture of socially responsible initiatives implemented during the pandemic. The risk/opportunity assessment was carried out, using the proposed model, by a group of experienced CSR and risk assessment specialists. The specialists were familiarized with the details of the initiative and its specificity, as well as categories, risk/opportunity factors, and scales used in the proposed risk/opportunity assessment model. The analysis results are presented in Table 9.

Table 9. Probability and consequences assessment for risks/opportunities for chosen CSR actions aiming to fight with COVID-19.

\begin{tabular}{|c|c|c|c|c|c|c|c|c|c|c|c|c|c|c|c|c|c|c|}
\hline \multirow[b]{3}{*}{ Category } & \multicolumn{3}{|c|}{ D4 } & \multicolumn{6}{|c|}{ D5 } & \multicolumn{9}{|c|}{ D6 } \\
\hline & \multicolumn{3}{|c|}{ Risk } & \multicolumn{3}{|c|}{ Opportunity } & \multicolumn{3}{|c|}{ Risk } & \multicolumn{3}{|c|}{ Opportunity } & \multicolumn{3}{|c|}{ Risk } & \multicolumn{3}{|c|}{ Opportunity } \\
\hline & $\mathbf{P}$ & $\mathrm{C}$ & $\mathbf{R}$ & $\mathbf{P}$ & $\mathrm{C}$ & $\mathrm{O}$ & $\mathbf{P}$ & $\mathrm{C}$ & $\mathbf{R}$ & $\mathbf{P}$ & $\mathrm{C}$ & $\mathrm{O}$ & $\mathbf{P}$ & $\mathrm{C}$ & $\mathbf{R}$ & $\mathbf{P}$ & $\mathrm{C}$ & $\mathrm{O}$ \\
\hline Significance & 1 & 1 & 1 & 3 & 4.5 & 13.5 & 1 & 1 & 1 & 3 & 4 & 12 & 1 & 1 & 1 & 3 & 4 & 12 \\
\hline Financial & 1 & 1 & 1 & 3 & 3 & 9 & 2 & 5 & 10 & 2 & 5 & 10 & 1 & 3 & 3 & 3 & 3 & 9 \\
\hline Reputational & 1 & 1 & 1 & 3 & 4.5 & 13.5 & 2 & 5 & 10 & 2 & 5 & 10 & 1 & 1 & 1 & 3 & 5 & 15 \\
\hline Strategic & 1 & 1 & 1 & 3 & 2 & 6 & 2 & 4 & 8 & 2 & 4 & 8 & 1 & 3 & 3 & 2 & 1 & 2 \\
\hline Operational & 1 & 1 & 1 & - & - & - & 2 & 5 & 10 & - & - & - & 2 & 2 & 4 & - & - & - \\
\hline Safety and legalliability & 1 & 1 & 1 & - & - & - & 2 & 3 & 6 & - & - & - & 1 & 1 & 1 & - & - & - \\
\hline
\end{tabular}

Figure 7 presents radial charts showing risk and opportunity levels for initiatives D4, D5 and D5.

The conducted risk and opportunity analysis for the $\mathrm{D} 4$ initiative reveals that the risk levels for individual categories are low and, therefore, acceptable (1 point). It is recommended to monitor them. The largest opportunities are in Significance and Reputational (13.5 points) categories, slightly smaller in Financial (9 points), and Strategic (6 points) categories. It can be seen that, for all analyzed categories, the opportunities are greater than the risks. It indicates the purposefulness, and sensibility, of taking this initiative without the need to introduce risk treatment strategies. 

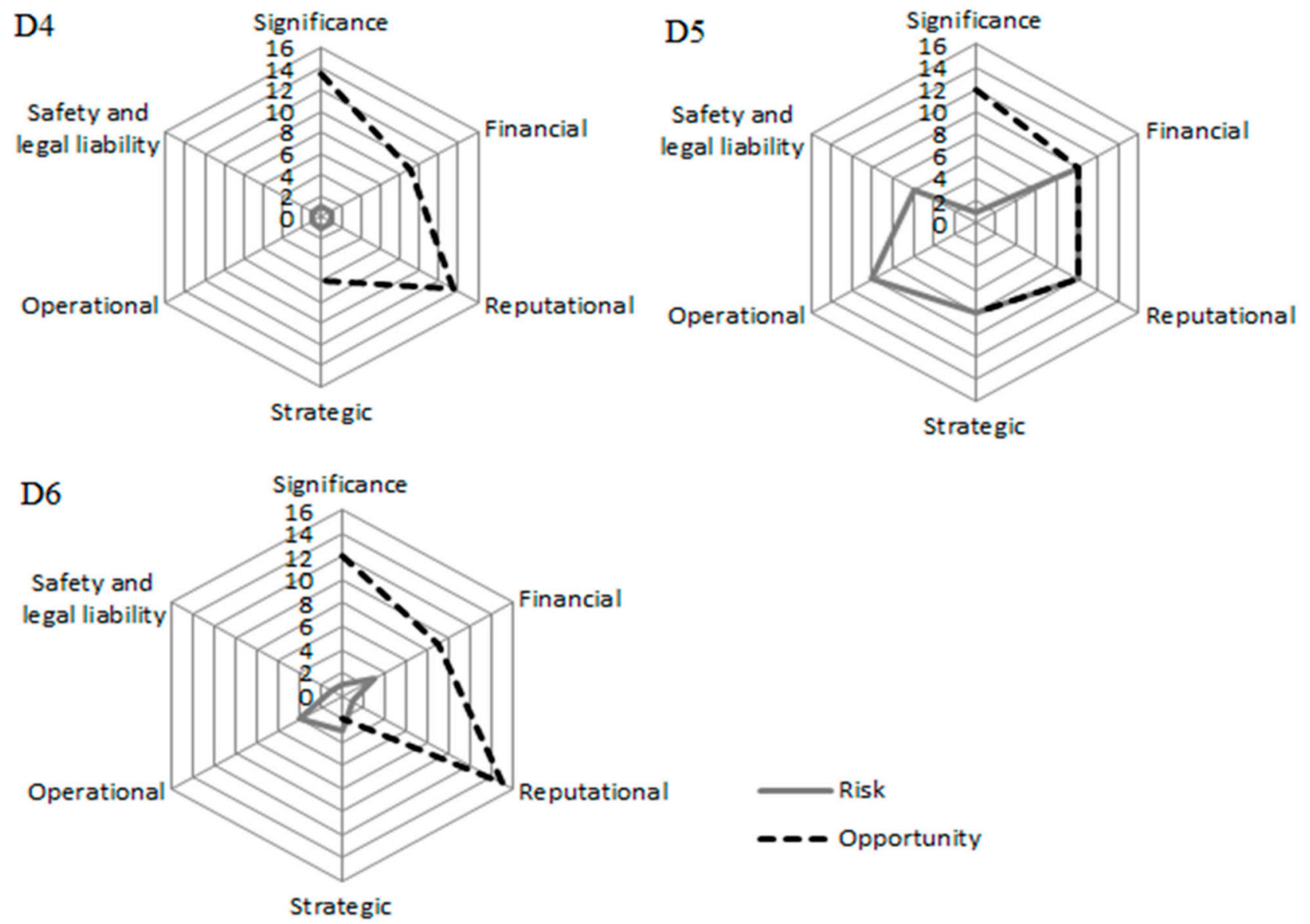

Figure 7. Risk and opportunity levels for individual analyzed initiatives.

The conducted risk and opportunity analysis for the D5 initiative shows that the risk levels for Financial, Operational, and Reputational categories are unacceptable (10 points), and their absolute reduction is recommended. For the category Strategic, risk level is 8 points, and for the category Safety, the level is 6 points (controlled level), so it should be reduced. The lowest level of risk was obtained in the category Significance (1 point) acceptable level, so it is recommended to monitor the risk. However, the largest opportunities are in Significance (12 points), Financial and Reputational (10 points) categories, slightly smaller in the Strategic (8 points) category. In the analyzed case, it is interesting that, in Financial, Reputational and Strategic categories, the level of risk is the same as the level of opportunity. Therefore, risks in these categories should be carefully managed. It can also be seen that, for Significance, the opportunities far outweigh the risks.

The risk and opportunity assessment for the D6 initiative reveals that the highest risk was obtained for the Operational category (6 points), and it is a controlled level of risk, therefore, its reduction is recommended. In Financial category, 3 points were obtained, therefore, it is an acceptable risk level and its monitoring is recommended. Acceptable risk levels were also obtained for the remaining categories. On the other hand, the largest opportunities are in the categories of Reputational (15 points), Significance ( 9 points), and Financial (6 points). The lowest opportunities were obtained for Strategic category (2 points). It can be noticed that, in all analyzed categories, except Strategic, the opportunities exceed the risks.

\section{Conclusions}

The paper concerns an important and current problem of taking initiatives in the field of Corporate Social Responsibility (CSR) in the specific market conditions of the COVID-19 pandemic. Thanks to the survey, interviews, in the form of conversations with respondents, 
and brainstorming sessions, it was possible to find answers to the given research problems RQ1-RQ5. The authors verified how the students and seniors assess the involvement of enterprises in undertaking socially responsible activities in the time of a pandemic. The research allowed us to identify those socially responsible activities that are considered the most important in the fight against the pandemic and showed that regardless of the characteristics differentiating social activities (type and number of beneficiaries, duration, geographic scope, etc.) The research has confirmed that undertaking social activities generally contributes to improving the image of enterprises. However, in some groups of beneficiaries it is possible to identify socially responsible activities that had a negative impact on the company's image.

Students and seniors most often declared that CSR activities undertaken in order to combat the pandemic were sufficient, although in the case of seniors, the percentage of such responses was higher than among students. The research showed that the crisis caused by the pandemic influenced the growth of expectations of both surveyed groups, regarding the involvement of the business sphere in socially responsible activities, rather than before the outbreak of the COVID-19 pandemic.

Based on the results of the study, it should also be stated that seniors, much more often than students, declared the disinterestedness of enterprises engaging in the implementation of socially responsible activities. Students more often than seniors reported that undertaking CSR activities is motivated by the own benefits of enterprises.

It should be emphasized that undertaking CSR initiatives, especially in times of a pandemic, contributes to sustainable development. CSR activities can lead to the development of enterprises and society as a whole, bringing numerous benefits to companies and their stakeholders. However, CSR can sometimes lead to problems in companies. Therefore, it is recommended to conduct a risk and opportunity assessment. This paper is the first to propose a risk and opportunity assessment model for CSR initiatives and the first attempt to assess the opportunities and risks of CSR initiatives to combat coronavirus.

In this work, six categories of risks and four categories of opportunities connected with undertaking socially responsible initiatives by enterprises were identified. Besides this, 29 risk and opportunity factors were proposed. They were the basis for a new model development, which enables risk/opportunity assessment of CSR initiatives in the pandemic era. It is worth it to stress that the proposed model is based on universal assumptions and criteria, so that it can be used in any country struggling with the COVID-19 pandemic. The presented examples of applications of the model show that it can be an effective tool for organizations taking CSR actions allowing them to assess risk/opportunity levels. Moreover, it is a starting point for managing them to maximize chances and minimize threats. The limitation of this model is that it does not take into account the impact of introducing a risk response on the level of risk, and the impact of the enterprise's experience in introducing risk treatment reactions. That is why future research is oriented to developing a comprehensive model of risk/opportunity management, enabling us to consider risk treatment, and actions aiming to maximize chances.

The proposed methodology of risk and opportunity assessment can also be applied to other risk contexts, e.g., natural disasters, environmental engineering projects, and investment projects involving applications of sustainable technologies. The identified risk and opportunity categories cover the area of the mentioned application possibilities. However, the descriptions of risk/opportunity scales and risk/opportunity factors should be adjusted to the specificity of the problem being analyzed. Surveys and interviews with beneficiaries of CSR actions, which were a basis for development risk/opportunity factors, should be replaced with expert surveys and brainstorm sessions with experts in the analyzed fields. Thanks to the possibility of adapting this model to various areas where, risks/opportunities can be examined, it becomes a universal tool for assessing risks/opportunities. 
Author Contributions: Conceptualization, M.K.; methodology, M.K., K.K.; validation, M.K., K.K.; resources-data gathering, M.K., K.K.; data curation, M.K., K.K.; writing-original draft preparation, M.K., K.K.; writing-review and editing, M.K., K.K.; visualization, M.K., K.K.; supervision, M.K. All authors have read and agreed to the published version of the manuscript.

Funding: This research received no external funding.

Institutional Review Board Statement: Not applicable.

Informed Consent Statement: Informed consent was obtained from all subjects involved in the study.

Data Availability Statement: The data presented in this study are available on request from thcorresponding author.

Conflicts of Interest: The authors declare no conflict of interest.

\section{References}

1. Shereen, M.A.; Khan, S.; Kazmi, A.; Bashir, N.; Siddique, R. COVID-19 infection: Origin, transmission, and characteristics of human coronaviruses. J. Adv. Res. 2020, 24, 91-98. [CrossRef]

2. Atkeson, A. What will be the economic impact of COVID-19 in the us? NBER 2020, 26867, 1-27. [CrossRef]

3. McKibbin, W.J.; Fernando, R. The global macroeconomic impacts of COVID-19: Seven scenarios. CAMA Work. Pap. 2020, 19, 25. [CrossRef]

4. Dankiewicz, R.; Tworzydło, D.; Ostrowska-Dankiewicz, A. Distribution of Services Within the Call Center and Covid 19-A Case Study. WSEAS Trans. Bus. Econ. 2020, 17, 921-932. [CrossRef]

5. Hillmann, J.; Guenther, E. Organizational Resilience: A Valuable Construct for Management Research? Int. J. Manag. Rev. 2021, 23, 7-44. [CrossRef]

6. García-Sánchez, I.-M.; Amor-Esteban, V.; García-Sánchez, A. Different Leaders in a COVID-19 Scenario: CEO Altruism and Generous Discourse. Sustainability 2021, 13, 3841. [CrossRef]

7. Hadida, A.L.; Tarvainen, W.; Rose, J. Organizational Improvisation: A Consolidating Review and Framework. Int. J. Manag. Rev. 2014, 17, 437-459. [CrossRef]

8. Bailey, K.; Breslin, D. The COVID-19 Pandemic: What can we learn from past research in organizations and management? Int. J. Manag. Rev. 2021, 23, 3-6. [CrossRef]

9. Chłodnicka, H. Threat to Business Activity in Times of the Pandemic. WSEAS Trans. Bus. Econ. 2021, 18, 88-94. [CrossRef]

10. Sheehy, B. Defining CSR: Problems and Solutions. J. Bus. Ethic 2015, 131, 625-648. [CrossRef]

11. Kiliańska, K. The activity of socially responsible enterprise sasa factor supporting the improvement of the quality of life of the society (Działalność społecznie odpowiedzialnych przedsiębiorstw jako czynnik wspierający poprawę jakości życia społeczeństwa). Stud. Miscell. Oecon. 2017, 3, 355-366.

12. Kang, H.-H.; Liu, S.-B. Corporate social responsibility and corporate performance: A quantile regression approach. Qual. Quant. 2014, 48, 3311-3325. [CrossRef]

13. Sundström, A.; Hyder, A.S.; Chowdhury, E.H. Market-oriented CSR implementation in SMEs with sustainable innovations: An action research approach. Balt. J. Manag. 2020, 15, 775-795. [CrossRef]

14. McWilliams, A.; Siegel, D. Corporate Social Responsibility: A Theory of the Firm Perspective. Acad. Manag. Rev. 2001, 26, 117-127. [CrossRef]

15. Fassin, Y.; Van Rossem, A.; Buelens, M. Small-Business Owner-Managers' Perceptions of Business Ethics and CSR-Related Concepts. J. Bus. Ethic 2011, 98, 425-453. [CrossRef]

16. Behringer, K.; Szegedi, K. The Role Of CSR In Achieving Sustainable Development-The oretical Approach. Eur. Sci. J. 2016, 12, 10-25. [CrossRef]

17. Málovics, G.; Csigéné, N.N.; Kraus, S. The role of corporate social responsibility in strong sustainability. J. Soc. Econ. 2008, 37, 907-918. [CrossRef]

18. Perez-Batres, L.A.; Miller, V.V.; Pisani, M.J. CSR, Sustainability and the Meaning of Global Reporting for Latin American Corporations. J. Bus. Ethics 2010, 91, 193-209. [CrossRef]

19. International Organization for Standardization. ISO 26000 Guidance on Social Responsibility. Available online: https: / www.iso. org/files/live/sites/isoorg/files/archive/pdf/en/iso_26000_project_overview-es.pdf (accessed on 13 March 2021).

20. Steurer, R.; Langer, M.E.; Konrad, A.; Martinuzzi, A. Corporations, Stakeholders and Sustainable Development I: A Theoretical Exploration of Business-Society Relations. J. Bus. Ethics 2005, 61, 263-281. [CrossRef]

21. Ahmad, N.; Mahmood, A.; Han, H.; Ariza-Montes, A.; Vega-Muñoz, A.; Din, M.; Khan, G.I.; Ullah, Z. Sustainability as a “New Normal" for Modern Businesses: Are SMEs of Pakistan Ready to Adopt It? Sustainability 2021, 13, 1944. [CrossRef]

22. He, H.; Harris, L. The impact of COVID-19 pandemic on corporate social responsibility and marketing philosophy. J. Bus. Res. 2020, 116, 176-182. [CrossRef]

23. Boddewyn, J.; Doh, J. Global strategy and the collaboration of MNEs, NGOs, and the provisioning of collective goods in emerging markets. Glob. Strat. J. 2011, 1, 345-361. [CrossRef] 
24. Slager, R.; Gond, J.-P.; Moon, J. Standardization as Institutional Work: The Regulatory Power of a Responsible Investment Standard. Organ. Stud. 2012, 33, 763-790. [CrossRef]

25. Giacalone, M.; Santarcangelo, V.; Donvito, V.; Schiavone, O.; Massa, E. Big data for corporate social responsibility: Blockchain use in Gioia del Colle DOP. Qual. Quant. 2021, 1-27. [CrossRef]

26. Dangelico, R.M.; Pontrandolfo, P. Being 'Green and Competitive': The Impact of Environmental Actions and Collaborations on Firm Performance. Bus. Strat. Environ. 2015, 24, 413-430. [CrossRef]

27. Sen, S.; Bhattacharya, C. Does Doing Good Always Lead to Doing Better? Consumer Reactions to Corporate Social Responsibility. J. Mark. Res. 2001, 38, 225-243. [CrossRef]

28. Wei, J.; Wang, Y.; Zhu, W. Strategically manipulating social reputation by scheduling corporate social responsibility events. J. Public Aff. 2014, 14, 116-129. [CrossRef]

29. Lizarzaburu, E.R. Corporate Social Responsibility and Stakeholder Strategies: An Impactin Risk Management. J. Res. Mark. 2014, 2, 98-105. [CrossRef]

30. Lee, C.-Y. Does Corporate Social Responsibility Influence Customer Loyalty in the Taiwan Insurance Sector? The role of Corporate Image and Customer Satisfaction. J. Promot. Manag. 2019, 25, 43-64. [CrossRef]

31. Uhlig, M.R.H.; Mainardes, E.W.; Nossa, V. Corporate social responsibility and consumer's relationship intention. Corp. Soc. Responsib. Environ. Manag. 2020, 27, 313-324. [CrossRef]

32. Skudiene, V.; Auruskeviciene, V. The contribution of corporate social responsibility to internal employee motivation. Balt. J. Manag. 2012, 7, 49-67. [CrossRef]

33. Strautmanis, J. Employees' values orientation in the context of corporate social responsibility. Balt. J. Manag. 2008, 3, 346-358. [CrossRef]

34. Karman, A.; Savanevičienè, A. Enhancing dynamic capabilities to improve sustainable competitiveness: Insights from research on organisations of the Baltic region. Balt. J. Manag. 2020, 16, 318-341. [CrossRef]

35. Helm, S. The Role of Corporate Reputation in Determining Investor Satisfaction and Loyalty. Corp. Reput. Rev. 2007, 10, 22-37. [CrossRef]

36. Pipatprapa, A.; Huang, H.-H.; Huang, C.-H. The Role of Quality Management \& Innovativeness on Green Performance. Corp. Soc. Responsib. Environ. Manag. 2017, 24, 249-260. [CrossRef]

37. Bhattacharya, C.B.; Sen, S.; Korschun, D. Using corporate social responsibility to win the war for talent. MIT Sloan Manag. Rev. 2008, 49, 37-44.

38. Kiliańska, K. Endogenous barriers in the implementation of corporate social responsibility (Endogeniczne bariery wdrażania społecznej odpowiedzialności przedsiębiorstw). Stud. Mater. Miscell. Oecon. 2018, 2, 189-200.

39. Banerjee, S.B. Corporate Social Responsibility: The Good, the Bad and the Ugly; Edward Elgar Publishing: Cheltenham, UK, 2007. [CrossRef]

40. Ho, J.; Lu, C.; Lucianetti, L. Does engaging in corporate social responsibility activities influence firm performance? The moderating effects of risk preferences and performance measurement systems. Manag. Decis. 2021, 59, 15-37. [CrossRef]

41. Göçer, A.; Jin, Y.H.; Fawcett, S.E. How Does the Contingent Sustainability-Risk-Cost Relationship Affect the Viability of CSR? An Emerging Economy Perspective. Sustainability 2019, 11, 5435. [CrossRef]

42. Wiśniewski, M. CSR risk management. Forum Sci. Oecon. 2015, 3, 17-24.

43. Kuo, Y.-F.; Lin, Y.-M.; Chien, H.-F. Corporate social responsibility, enterprise risk management, and real earnings management: Evidence from managerial confidence. Finance Res. Lett. 2020, 101805. [CrossRef]

44. Boubaker, S.; Cellier, A.; Manita, R.; Saeed, A. Does corporate social responsibility reduce financial distress risk? Econ. Model. 2020, 91, 835-851. [CrossRef]

45. Krechowicz, M. Effective Risk Management in Innovative Projects: A Case Study of the Construction of Energy-efficient, Sustainable Building of the Laboratory of Intelligent Building in Cracow. IOP Conf. Ser. Mater. Sci. Eng. 2017, 245, 62006. [CrossRef]

46. ISO (International Organization for Standarization). 31000:2018. Risk Management_Guidelines; ISO: Geneva, Switzerland, 2018.

47. Krechowicz, M. Comprehensive Risk Management in Horizontal Directional Drilling Projects. J. Constr. Eng. Manag. 2020, 146, 04020034. [CrossRef]

48. Rak, J.; Tchórzewska-Cieślak, B. Five-parametric matrix to estimate the risk connected with water supply system operation. Environ. Prot. Eng. 2006, 32, 38-46.

49. Krechowicz, M. Risk Management in Complex Construction Projects that Apply Renewable Energy Sources: A Case Study of the Realization Phase of the Energ is Educational and Research Intelligent Building. IOP Conf. Ser. Mater. Sci. Eng. 2017, 245, 062007. [CrossRef]

50. Krechowicz, M. The hybrid Fuzzy Fault and Event Tree analysis in the geotechnical risk management in HDD projects. Georisk Assess. Manag. Risk Eng. Syst. Geohazards 2021, 15, 12-26. [CrossRef]

51. Rak, J.; Tchórzewska-Cieślak, B. Risk in the Operation of Collective Water Supply Systems(Ryzyko w Eksploatacji Systemów Zbiorowego Zaopatrzenia Wodę); Oficyna Wydawnicza Politechniki Rzeszowskiej: Rzeszów, Poland, 2013; p. 164.

52. Nuchpho, P.; Nansaarng, S.; Pongpullponsak, A. Risk Assessment in the Organization by using FMEA Innovation: ALiterature Review. In Proceedings of the 7th International Conferenceon Educational Reform (ICER2014), Innovations and Good Practices in Education: Global Perspectives, Huế, Vietnam, 15 March 2014; pp. 781-789. 
53. Krechowicz, M. Qualitative risk assessment of passive house design and construction processes. In Proceedings of the 5th World Multidisciplinary Civil Engineering-Architecture-Urban Planning Symposium-WMCAUS, Prague, Czech Republic, 15-19 June 2020; IOP Publishing: Bristol, UK, 2020; p. 042068. [CrossRef]

54. Aziz, S.; Dowling, M. Machine Learning and AIfor Risk Management. In Disrupting Finance: Fin Tech and Strategy in the 21st Century; Lynn, T., Mooney, J.G., Rosati, P., Cummins, M., Eds.; Springer International Publishing: Cham, Switzerland, 2019; pp. 33-50.

55. Hegde, J.; Rokseth, B. Applications of machine learning methods for engineering risk assessment-A review. Saf. Sci. 2020, 122, 104492. [CrossRef]

56. Krechowicz, M.; Krechowicz, A. Risk Assessment in Energy Infrastructure Installations by Horizontal Directional Drilling Using Machine Learning. Energies 2021, 14, 289. [CrossRef]

57. Perrotta, F.; Corbi, G.; Mazzeo, G.; Boccia, M.; Aronne, L.; D’Agnano, V.; Komici, K.; Mazzarella, G.; Parrella, R.; Bianco, A. COVID-19 and the elderly: Insights into pathogenesis and clinical decision-making. Aging Clin. Exp. Res. 2020, 32, 1599-1608. [CrossRef] [PubMed]

58. Mueller, A.L.; McNamara, M.; Sinclair, D.A. Why does COVID-19 disproportionately affect older people? Aging 2020, 12, 9959-9981. [CrossRef] [PubMed]

59. Consumer Federation. Digital Divide During the Pandemic. Access and Use of the Internet and Computers in Selected Social Groups (Federacja Konsumentów. Wykluczenie Cyfrowe Podczas Pandemii. Dostęp Oraz Korzystaniez Internetui Komputeraw Wybranych Grupach Społecznych). Available online: http://www.federacja-konsumentow.org.pl/p,1689,dad1c,raport-fk-wykluczenie-cyfrowe.pdf (accessed on 22 May 2021).

60. Orlen Jednak się ugiął. Po krytyce cena Płynu do Dezynfekcji obniżona z 95 zł do 49 zł. 2020. Available online: https://www. wiadomoscihandlowe.pl/artykul/orlen-jednak-sie-ugial-po-krytyce-cena-plynu-do-dezynfekcji-obnizona-z-95-zl-do-49-zl (accessed on 13 March 2021). 